\title{
Kastrup, en hedensk offerplads
}

\section{Af Hans Neumann.}

Det er muligt, at nogle har læst så mange beretninger om, hvad man ved udgravninger har fảet at vide om oldtidsforhold, at de er blevet blaserte og tror, at det er en selvfølge, at man ved både det ene og det andet. Men det er ingen selvf $\emptyset$ lge. Vi, hvis arbejde det er ikke blot at finde nogle genstande, men gennem sporene $\mathbf{i}$ jorden at komme livet og menneskene $i$ oldtiden på nærmere hold, ved, at de mange århundreder, der skiller, er en modstand, som det er vanskeligt at overvinde. Og vi ved også, at fundene samler sig om nogle få sider af kulturlivet, mens andre vigtige områder næsten ikke er til at komme nær.

Fra arkæologiens barndom har fund af grave med deres indhold været vor vigtigste kilde, og ganske vist er alt, hvad der vedrører $d \varnothing d$ og begravelse og menneskenes forhold til de afd $\varnothing d e$ en vigtig side af kulturlivet, men det er dog en meget speciel side. Dertil er senere kommet bopladserne, fund af huse med deres indhold, som især er talrige fra århundrederne omkring Kr. f., og som har fortalt os meget om menneskenes daglige tilværelse og om $\emptyset$ konomiske og sociale forhold.

Det har jo virkelig vist sig, at det ikke alene er den materielle kultur, vi ved fundenes hjælp kan få kendskab til; også det åndelige liv, menneskenes forhold til de overnaturlige magter, som de følte sig omgivet af, deres gudeverden, hvis man kan bruge dette udtryk, kan fund og iagttagelser give os et indblik i. Vsikkert og ufuldstændigt er det, men noget synes man vilde være vundet, hvis vi i hvert fald kendte det religiøse livs materielle side, den hedenske gudsdyrkelses ydre apparat her i landet. Vi ved, at det har eksisteret, allerede stenalderen havde det, således som det ses af en stor kultbygning, der for nylig er fremdraget ved Tru- 
strup på Djursland. 1) De vældige rejste stenblokke ved Stonehenge i England viser, hvad man kunde bygge, og antyder, at der har været meget mere, end vi ved noget om. Fra en senere tid ved vi, at der var både gudebilleder og bygninger, men hvordan så de ud? Og hvad havde man rundt omkring i bygderne? Hvordan så der ud på deres hellige steder, og hvad foregik der ved festtiderne og til daglig?

Vi kan slet ikke besvare disse spørgsmål, for fundene lader os på en mærkelig måde i stikken. Meget tyder på, at den katolske kirke ved sin fremtrængen her $i$ landet $i$ bogstavelig forstand har sat sig på hedenskabet. Ikke få steder er der fundet spor af hedenske gudehov under vore kirker; derved er meget forsvundet og en vigtig side af hedenskabet blevet morkelagt. I hvert fald er den udgravning, som der her skal gøres rede for, udgravningen af en stor hedensk of ferplads, stadig den eneste af denne art, og derfor er det rimeligt at give nøje agt på, hvad den fortæller.

Kastrup ligger lidt sydøst for Gram og altså på den vestlige spids af en bakke $\varnothing$, der skyder sig ind imellem Gram å mod nord og Gelså mod syd. I nærheden af Gram har der i oldtiden været en vigtig overgang over Gram å, idet en vejlinie, der nordvest fra kom fra de store bygder ved Kongeåen og over Harreby s $\phi$ gte langs skovranden ned til Gram, derefter syd for åen s $\varnothing$ gte $\varnothing$ stpå over Nustrup til hærvejen ved Vojens.

Sandsynligvis er netop ved Kastrup en anden vej gået mod sydøst over Brøndlund og $\AA$ b $\varnothing l$ mod Tirslund. I hvert fald ligger offerpladsen ved en af de stærkt befærdede vejlinier fra oldtiden.

Lidt vest for Søren Krabs gård i Kastrup var der på marken en lav forh $\phi$ jning. Som så mange andre af samme art blev den anset for en overpløjet gravh $\varnothing \mathrm{j}$, men den viste den ejendommelighed, at overfladen var fuld af potteskår. De kunde alle dateres til tiden efter Kr. f., snarest det 2. århundrede.

Ved den derpå f $\varnothing$ lgende unders $\varnothing$ gelse, som grdj. Krab beredvilligt gav sin tilladelse til, viste det sig, at højen foruden skårene rummede en mængde små sten. På planen (fig. 1) vil man se,

1) P. Kiærum: Et tempelhus fra stenalderen, Kuml, 1955, s. 1. 


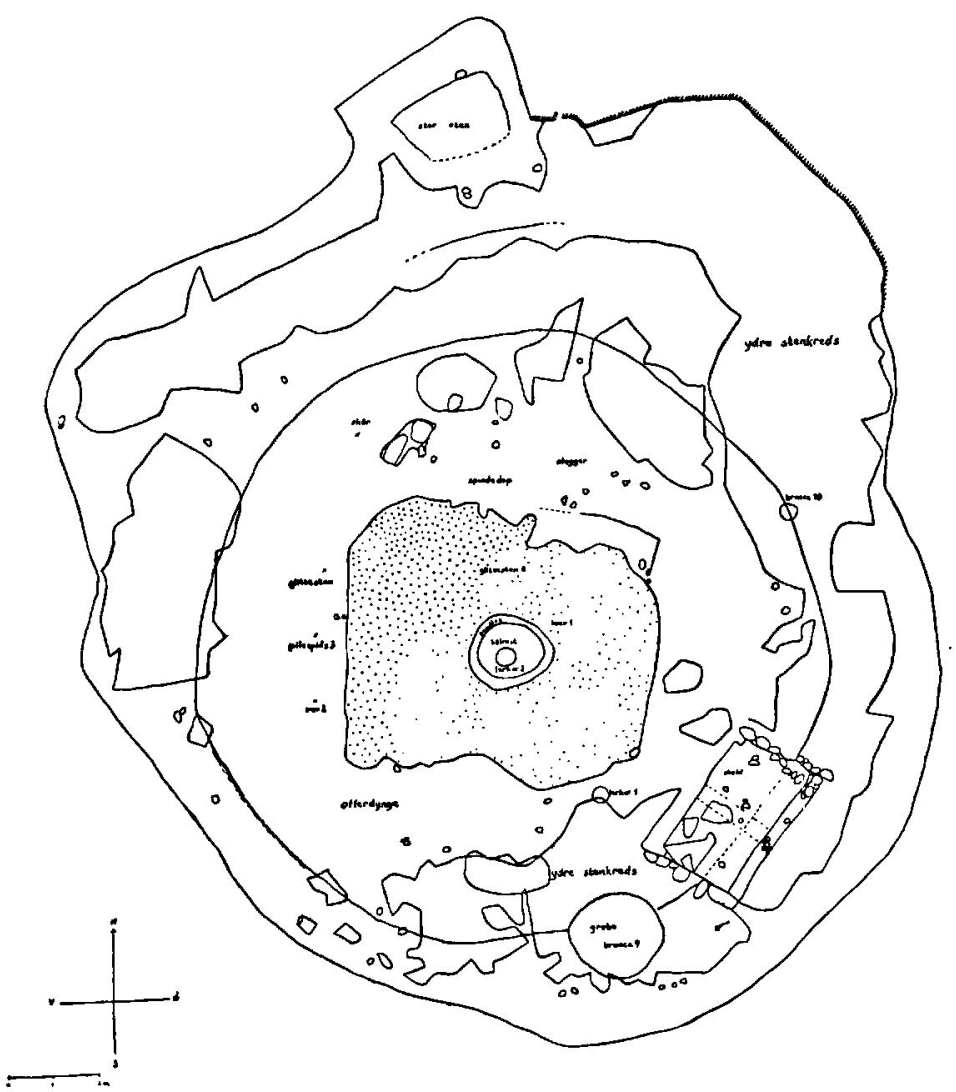

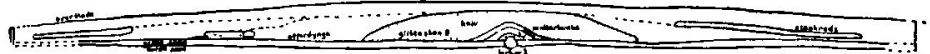

sentI $a$

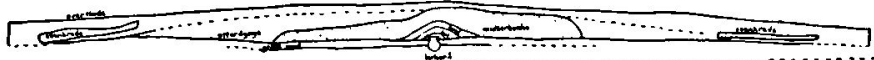

Fig. 1. Plan over fundstedet.

at de stort set fordeler sig på en stenbunke i midten og en bred stenkreds uden om. Rummet derimellem var stenfrit med unātagelse af nogle mindre pletter med sten; de lå $i$ samme niveau som den ydre stenkreds og har sikkert oprindelig været sammenhængende med den, for man fortalte, at der ved pløjning 
var fjernet mange sten $\mathrm{i}$ tidens løb. Den ydre stenkreds bestod af et enkelt lag sten, der lå $i$ et niveau, der fra alle sider var stigende ind mod midten, og det er sandsynligt, at den oprindeligt er nået helt over midten som en brolægning over hele højen, men at ploven har fjernet alt det фverste. Således brolagt må vi sikkert forestille os anlæget i dets sidste tid, og da har den midterste stenbunke været skjult nedenunder ${ }^{2}$ ). - På planen ses det endvidere, at den ydre stenkreds $i$ nordsiden har et mere lige forløb; der kan ikke gives nogen forklaring på denne uregelmæssighed og anlæget er ellers cirkelrundt. Den ydre stenkreds har ef tværmål på $18 \mathrm{~m}$ i øst-vest og $20 \mathrm{~m}$ i nord-syd, men den har ikke nogen »fast « afslutning udad (jfr. fig. 2 ).

Stenbunken i midten var, da den var helt frigravet, ca. $65 \mathrm{~cm}$ højj og dens bundflade ca. $3 \times 4 \mathrm{~m}$. Toppen nåede op til pløjelaget, og den har da oprindelig sikkert været h $\varnothing$ jere. Hvad denne bunke gemte kunde vi ikke vide, men vor nysgerrighed var betydeligt skærpet ved undersøgelsen af dens omgivelser, af det stenfri parti mellem midterbunken og den ydre stenkreds.

Dette parti, som jeg straks vil kalde offerdyngen, bestod kun for en mindre del af jord, og »jorden « var rødlig eller grå eller mørkfarvet af trækul. Egentlige bålrester fandtes dog ikke. Desuden var der mange, svagt brændte lerflager uden kendelig form, nogle få, brændte dyreben, der viste sig at være af hest, ko eller svin, $\left.{ }^{3}\right)$ ganske få og små oldsager og endelig en stor mangde potteskår. Det var åbenbart fra dette lag at skårene i pløjelaget stammede. Deres antal løber op i mange tusinde og deres vagt kan forsigtigt anslås til ca. $450 \mathrm{~kg}$.

Skårene var åbenbart en væsentlig del af dyngens indhold,

2) På planen er stenkredsen mod sydøst afbrudt af en vandret liggende kvadratisk stenbro med en fordybet stenbrolagt rende. Kloge bes $\varnothing$ gende fortalte under udgravningen, at denne stenbro var beregnet til processioner, der kommende fra sydøst førtes ind mod anlagets centrum. En stedlig tilskuer sagde dertil:- Jeg tror, det er en gammeI gedestald. Og det var det. Stalden er senere gravet ind i højen og har ikke noget med anlæget at gøre.

s) Jeg er dr. Degerbøl, Zoologisk Museum, megen tak skyldig for bestemmelse af disse og andre knogler fra dette fund. 


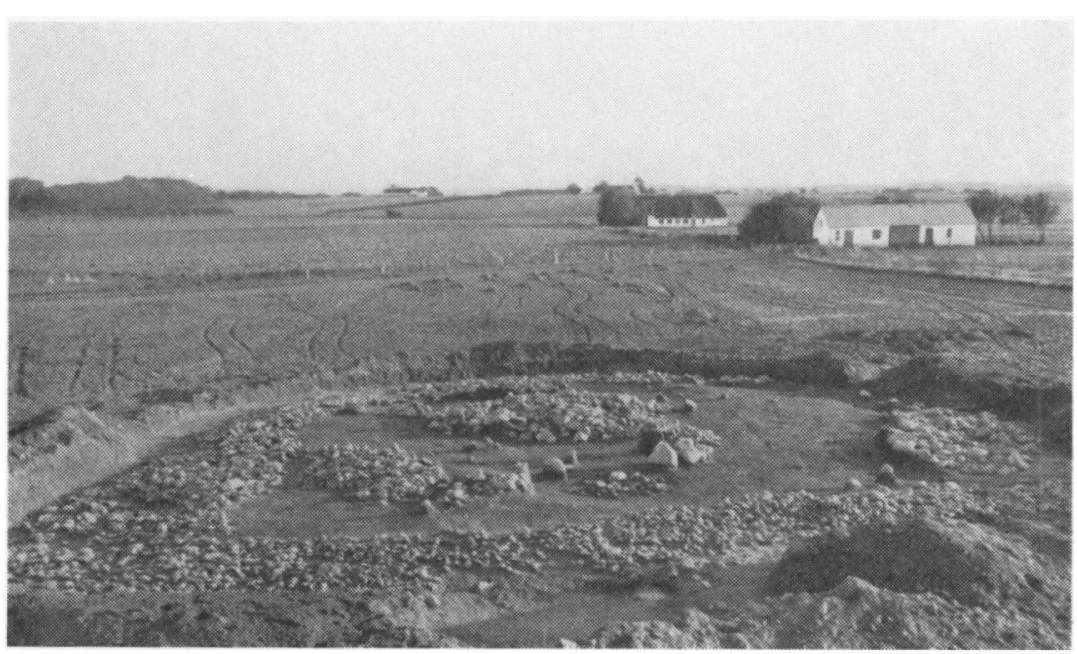

Fig. 2. Offerplads, fra nord.

men de lå ganske spredt, og hjemme i museet viste sig det mærkelige, at de ikke kunne samles til hele kar. Ret hurtigt samlede vi to små skåle af ældre romertids form, og af dem var næsten alle skår bevaret, men af de andre mange fik vi ikke så meget som en skårflage til trods for, at der var ornamenter og former nok at rette sig efter. Hvorfor fandt vi af de to skåle næesten alle skår, men af de andre hundreder af kar kun et? Målt med vore mange andre erfaringer kommer man ikke uden om, at den nærliggende tanke, at skårene er de ituslåede kar, som man kom med offergaver $i$, må af vises. Man har ikke of ret hele lerkar, men skår. Det er indenfor religionshistorien ikke ukendt, at man fandt det tilladeligt $i$ 'stedet for et hele at ofre en erstatning eller en lille del, og netop Kastrupfundet vil senere vise ét sikkert eksempel på den samme tanke.

To særlige ofre fandtes $i$ offerdyngen. Bronce $10 \mathrm{er}$ en klump dårligt bevarede genstande af bronce og jern, bl. a. en kornsegl og en sammenslået fingerring af guld. Lerkar 1 (fig. 3) er et $41 \mathrm{~cm}$ højt lerkar fra den ældre romertid, ca. $150-200$ e. Kr. f. Det har på underdelen et malet ornament af runde pletter, som kendes fra nogle få lerkar fra denne del af landet. Det var ontrent fyldt 


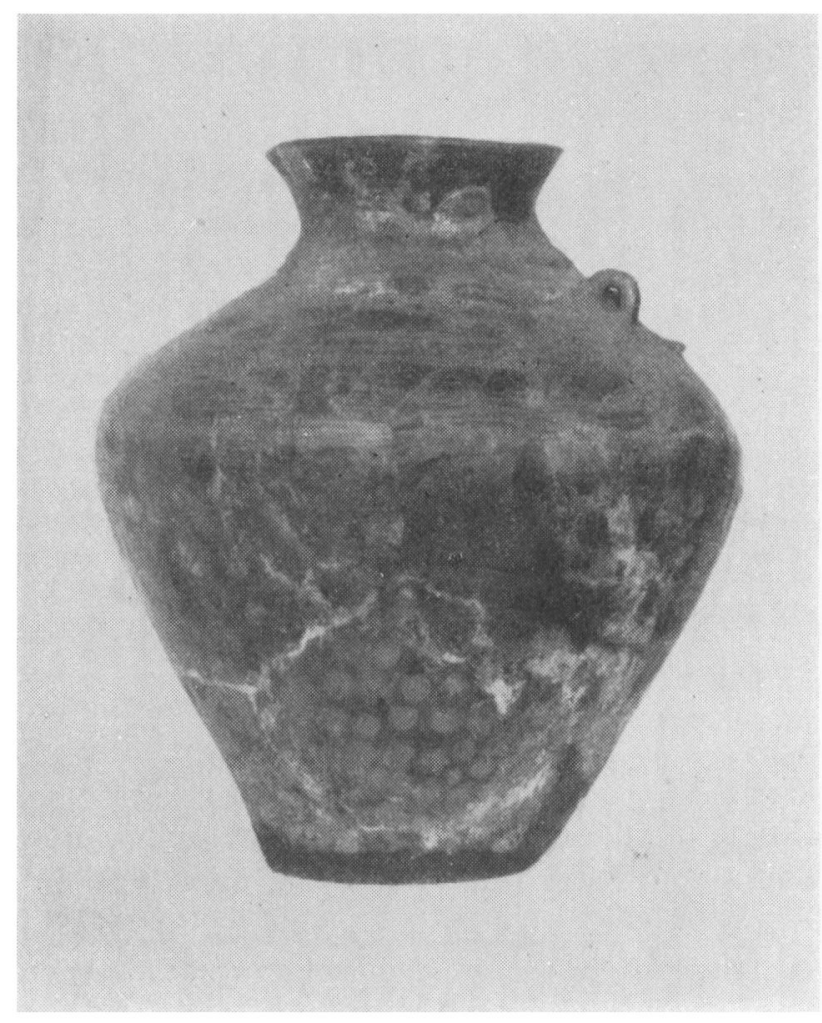

Fig. 3. Lerkar.

med oldsager: 7 stykker af tykke jernstænger, 2 spydspidser, 2 hankeringe til et stort kar, 2 sporer, skjoldhåndtag og skjoldbule, kniv, spænder, sværd og et par ornamenterede sølvbeslag. Desuden nogle fåreknogler. - Altså ingen gravurne, men et særligt værdifuldt offer nedsat $i$ offerdyngen.

Denne offerdynge lå altså udenom og henover midterbunken og strakte sig ud under den ydre stenkreds. Vigtigt er, at den ydre stenkreds ikke ligger direkte ned på det yderste af offerdyngen. Imellem ligger et jordlag uden skår eller andre kulturspor. På et tidspunkt, da offerdyngens vækst er standset, fordi offerhandlingerne har skiftet karakter, har man lagt et jordlag 


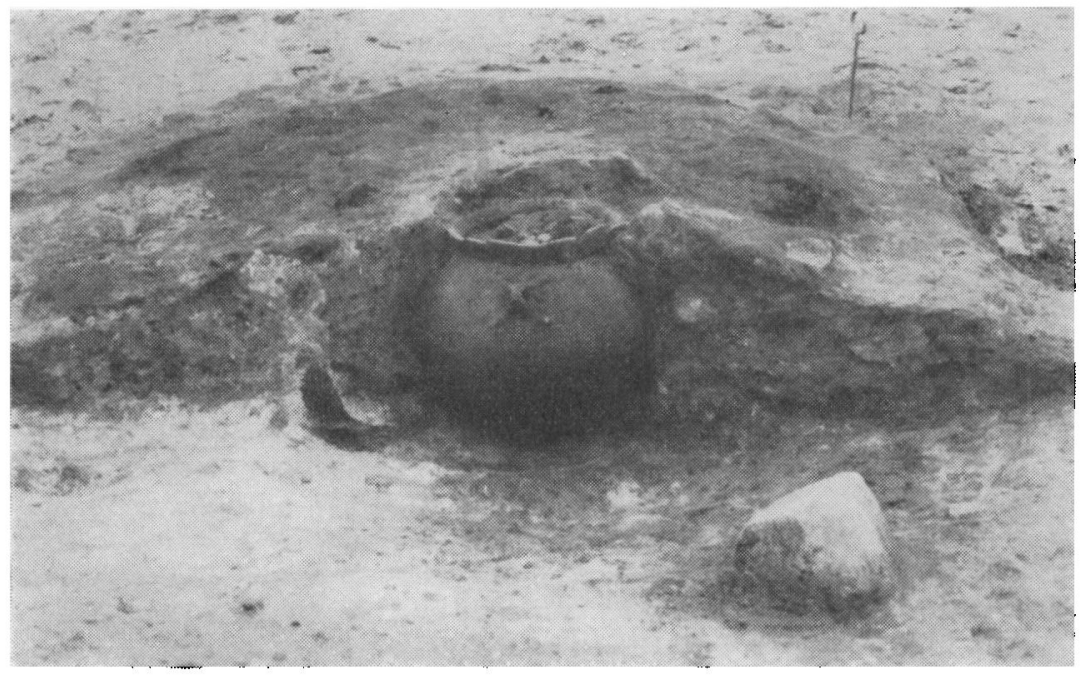

Fig. 4. Det centrale lerkar under bálresten.

rundt om dyngen og f $\varnothing$ rst derpå brolagt overfladen. Vi ved ikke, hvornår brolægningen er sket.

Offerdyngen havde på dette tidspunkt et tværmål på $14 \mathrm{~m}$. Den afsluttes udad af en så regelmæssig cirkel og dennes centrum ligger således $\mathrm{i}$ forhold til stendyngen, at man har svært ved at tro, at dette er tilfældigt. Forholdet forklares bedst ved antagelsen af, at stendyngen foroven har haft et midtpunkt, som vi nu ikke kender, og at dyngen er holdt cirkelrund omkring dette.

På dette tidspunkt af undersøgelsen havde vi set så mange ukendte og uforståelige ting, at vi var spændte på, hvad den midterste stenbunke rummede. Det var åbenbart den, det hele drejede sig om. Vi måtte vide, om den altid havde været en stenbunke, eller om den var en sammenstyrtet rest af et eller andet opbygget.

Det var en stenbunke. Det eneste, vi så, var, at nogle steder var de nederste sten ikke kastet tilfældigt sammen, men var stillet sammen, omtrent som når man læner kornsække mod hin- 
anden. Altså dog et fingerpeg om, at mennesker havde haft en hensigt med det.

Inde $i$ midten var der ingen sten, men en bunke sand. Det var ganske hvidt og så fint, at det melede $\mathrm{i}$ hånden, når man tog $\mathrm{i}$ det. Sådant sand fandtes ikke på stedet. Det lå i en ret stejl, kegleformet bunke, der forneden var lidt over $1 \mathrm{~m}$ stor.

Sandet viste sig at ligge $i$ et $6 \mathrm{~cm}$ tykt lag over en bunke kulsort jord, åbenbart resten af et kraftigt bål. I denne bålrest fandtes forskellige, tildels halvsmeltede småting, deriblandt stykker af sådanne broncekæder, som kendes fra romersk jernalders drikkehorn.

Og under bålresten sad gravet lidt ned i sandet, men med halsen lidt op i kulbunken et stort lerkar (fig. 4); det var en velproportioneret krukke med tyk, facetteret rand og ornamenteret med furer, som vi så godt kender det fra denne tid.

Dette lerkar var da midtpunktet for hele anlæget, et lerkar gravet lidt ned i det grå sandlag som hele anlæget lå på. Selv om vi nok kunde vide, at det ikke var en almindelig gravurne, man havde of ret så megen omhu, var det dog med en vis spænding, vi undersøgte det hjemme i museet.

Lerkarret viste sig hurtigt at være så fuldt af metalsager, at vi måtte skille det ad for at undersøge det. Det var fyldt næsten til randen af sammenb $\varnothing$ jede og nu sammenrustede genstande af bronce og jern. Der var: en sammenslået broncekedel med jernhank, drikkehornsbeslag, kniv og saks,skjoldbule og skjoldhåndtag, 2 spydspidser, 4 sporer og på bunden lå et sammenbøjet jernsværd (fig. 5). Vi får nok aldrig at vide, hvorfor just disse genstande skulle med $i$ dette lerkar, men forunderligst var nok knoglerne: to fodrodsknogler af et får og et lillefingerled af et menneske!

Hele det anlæg, som der hidtil er fortalt om, lå på et lag af ensartet gråt sand. Det lå over hele pladsen i en tykkelse af ca. $10 \mathrm{~cm}$. I det hvide sand nedenunder så vi foruden spor af et ældre anlæg, nogle mærkelige m $\phi$ rke striber (fig. 6). De lå med en indbyrdes afstand af $20-25 \mathrm{~cm}$ og $\mathrm{i}$ tre retninger skråt over hinanden. Vi ved nu, at det er pløjestriber, og noget kunde tyde på, at de brede af striberne skyldes en muldfjælsplov, de smal- 


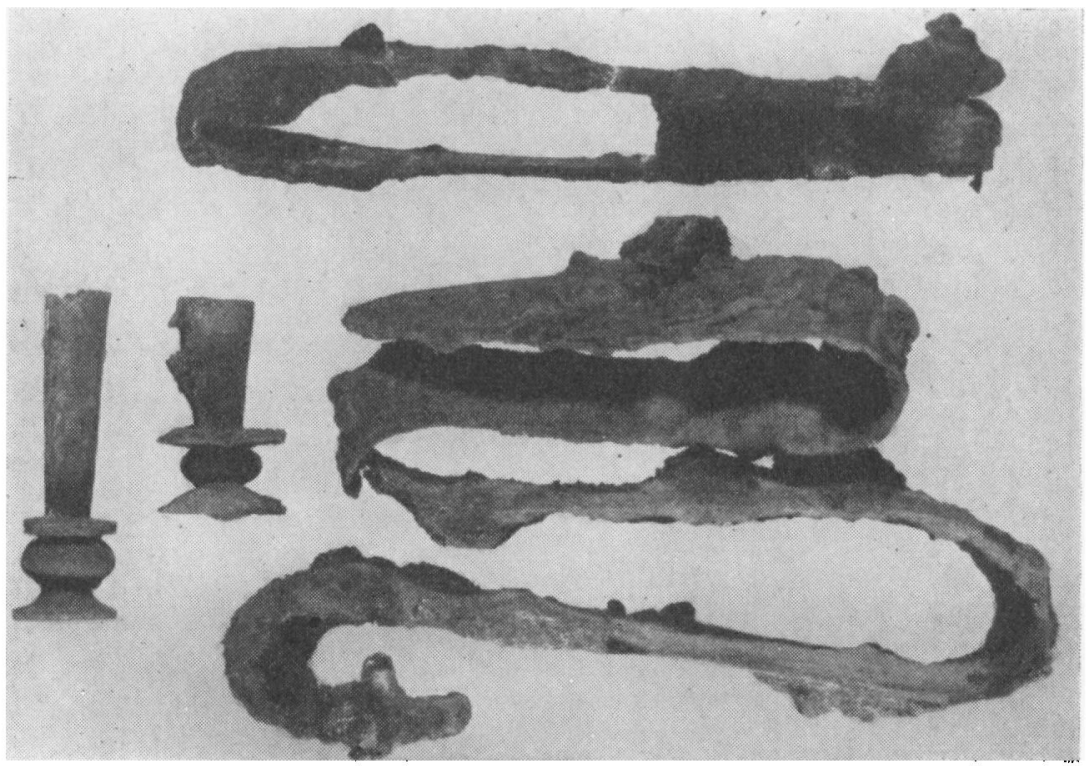

Fig. 5. Fra lerkar 2, Jernsverd, saks og drikkehornsbeslag.

lere derimod en ard. Man har pløjet hele pladsen og det grå sandlag er dannet ved denne pløjning.

Efter at vi ved selve unders $\varnothing$ gelsen og senere havde gjort de iagttagelser, som her er meddelt, meldte sig den ulige vanskeligere opgave at nå til en forståelse af dette fund. Det lignede ikke noget andet, vi kendte. En boplads som f $\varnothing$ rst antaget var det ikke, en grav var det heller ikke. Jeg måtte efterhånden lægge større og større vægt på, hvad ejeren en dag under udgravningen havde fortalt mig. Om dette sted på hans mark gik det sagn, at her ville man i sin tid bygge Gram kirke, men alt hvad der blev bygget om dagen blev revet ned igen om natten, og man kom ikke videre. Så besluttede man at bede Gud om et tegn. Man ville binde to kvier sammen og lade dem gă, og der hvor man fandt dem næste morgen, der ville man bygge kirken. Således fik Gram kirke anvist den plads, hvor den nu ligger.

I en præsteindberetning fra 1766 har vi samme sagn $i$ en lidt 
anden form. 》Der ligger en del store stene på Kastrup mark, som kaldes Gammel Kirke, hvorom er den tradition, at de er samlede her $i$ begyndelsen $i$ den absigt, at kirken skulle have stảet sammesteds, men blev dog intet af eftersom alt, hvad der blev opbygget om dagen, det blev forflyttet om natten hen til det sted, hvor den nu står.«

Dette er jo et af de almindeligste sagn, udbredt over hele landet og knyttet til et stort antal kirker. For eksempel er det på Als knyttet til 7 af фens 13 kirker. Der er sikkert flere grunde til, at dette sagn har vandret. Når kirken $f$. eks. har en ejendommelig beliggenhed $i$ sognet, har man grebet til dette sagn som en forklaring. Men disse sagn forstås ikke til fulde ved at kalde dem vandresagn. For det mest markelige ved dem er det, at man endnu så mange steder kan gå ud på marken og vise det sted, hvor man ville bygge kirken, men ikke fik det gjort.

Og hvad er så det for steder? Det er i mange tilfalde steder med sakralt klingende navne, steder hvortil der knytter sig overtro, eller hvor der skildres forhold, som ikke passer med de almindeligt kendte oldtidsminder.

Der skal her anføres nogle eksempler blandt mange. Hørup kirke på Als skulde oprindelig være bygget på Lundebjerg, men hver midnat kom nogle nisser og nedbrød det byggede og for hver sten, de tog ud sagde de »højere op, højere op «.") Ketting kirke skulle først være bygget på Knoldh $\emptyset j$, hvor nissekongen Knold boede, men det foruroligede troldene i de mange nærliggende høje, og byggematerialerne blev hver nat båret hen til en anden bakke. ${ }^{5}$ ) I Notmark sogn ligger en dysse Trodsten; på overliggeren findes en mængde skålformede fordybninger, og det fortælles, at det var en offersten, og at kirken skulle have været bygget her.") I Skærbæk kirkemur sidder en sten, hvori ses mærker af 5 fingre. Den er smidt af en kæmpe fra Kirkeh $\varnothing j$ på Vester Gasse mark efter det sted, hvor kirken skulle bygges. Kir-

4) Inger M. Boberg i Sønderjyske Årbøger, 1935, s. 93.

5) smst. s. 103.

) smst. s. 108 . 


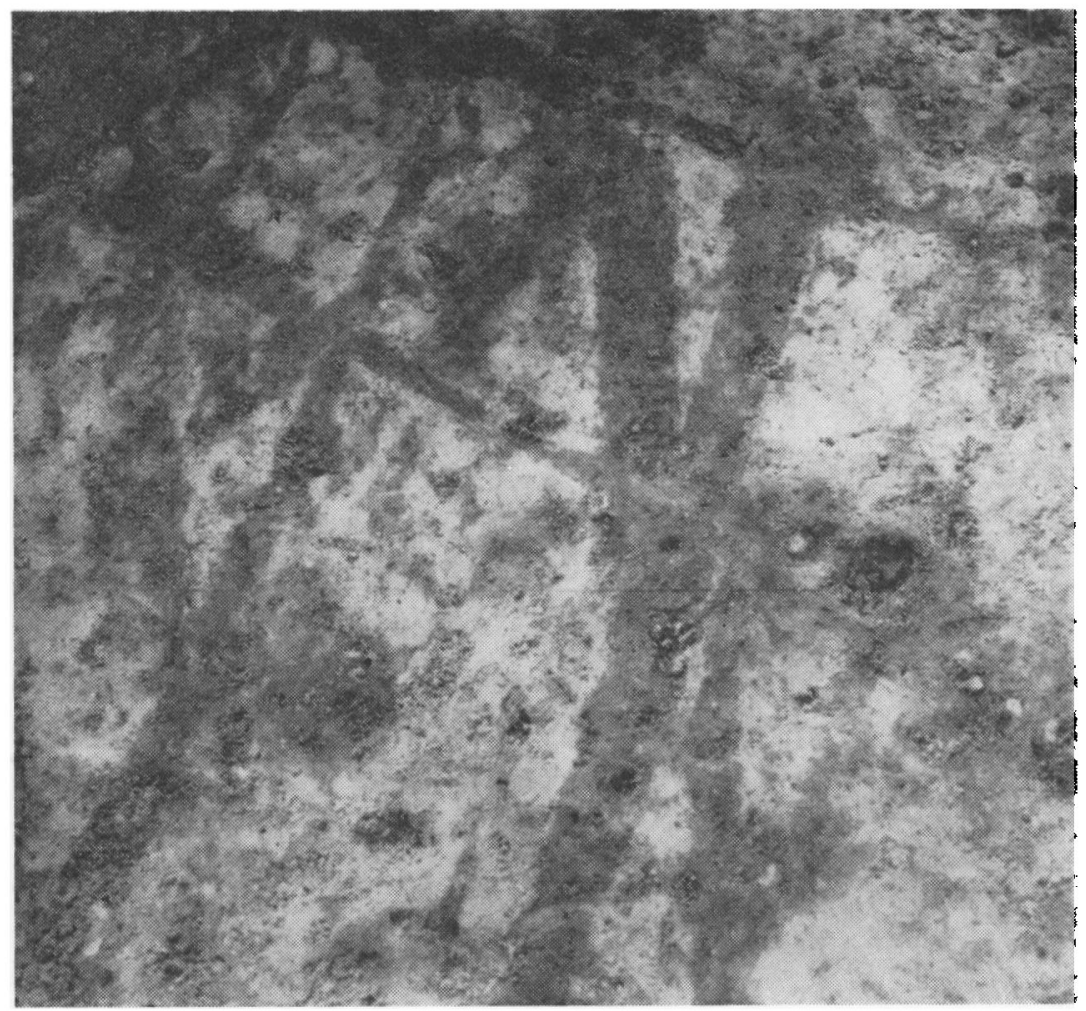

Fig. 6. Plojestriber $i$ den lyse undergrand.

ken skulle f $\phi$ rst være bygget der på Gasse mark.i) Noget $\emptyset$ stligere på Gasse mark huskes en stor sten, som hed offersten.

I Toftlund skulle kirken have været bygget på et sted, hvor vi nu kender en gravplads fra f $\varnothing$ rromersk jernalder og noget udf $\varnothing$ rligere fortælles om Landet kirke på Lolland, at den skulle være bygget på Tiulshøjmarken i Opager. Der var også indrettet kirkegård, men de d $\phi$ de ville ikke ligge der, »de løb derfra om natten «. Nu er der fundet grave fra vikingetid på dette sted, og der ville de kristne altså ikke begraves.. $\left.{ }^{8}\right)$ Smerup kirke på

7) Evald Tang Kristensen: Danske sagn III, 79.

8) Svend Jørgensen i Loll.-Falsters hist. Samfunds Årbog XXXII, 272. 
Sterns skulle oprindelig bygges ved Thorshøje by, men alt blev stadig revet ned, »fordi Thor og de andre trolde ikke ville tåle den der $\left.{ }^{9} .^{9}\right)$ Fanefjord kirke på Møen skal have ligget på Kirkebjerg, der er det højeste punkt i egnen. Præsten Paludan har hørt, at der $\emptyset$ verst har været en mægtig granitblok med 2 rækker sten udenom. Om natten brænder der ild på dets top. En godmodig troldinde bor i bjerget og rækker brød ud til de fattige på en skydsel. Undertiden vil man også se underlige gestalter i præsteklæder på bjergets top, høre salmetoner og til sine tider igen veklager og frygtelíge skrig.

Disse eksempler må være nok. De er taget ud af en stor sagnkreds og har det tilfælles, at de fortæller om et sted, hvor man byggede kirken og et andet sted, hvor nogle vilde have bygget den. Og det er ikke svært at høre, at de to parter, diskussionen står imellem, er hedenskabet og kristendommen. De viser os den typiske modsætning mellem de to standpunkter, som har gjort sig gældende ved kristendommens indf $\varnothing$ relse: det radikale standpunkt, som vil bryde med det gamle og opføre kirken et nyt sted og det konservative standpunkt, som af taktiske eller ideelle grunde vil bevare kontinuiteten og blive på det gamle hellige sted.

I mange tilfælde blev kontinuiteten bevaret, man blev på stedet, således som det tilrådes $i$ et pavebrev til den danske kirke med den meget sigende tilf $\varnothing$ jelse, »fordi f $\varnothing$ dderne lettere finder vej til det vante sted «. Men $i$ andre tilfælde som i Kastrup og Thorsh $\varnothing j e$, sejrede hedenskabets afvisning. Vi h $\phi$ rer ikke, hvad hedenskabets mænd sagde, det er den katolske kirkes formulering, der siger, at kirken ikke blev bygget $i$ Thorsh $\phi j e ~ » f o r d i$ Thor og de andre trolde ikke ville tåle den der «.

Folkemindeforskningen kan jo fortælle mange ting om hedenskabets efterleven helt op imod vor tid, og taget som helhed giver denne sagnkreds et stærkt bevis på den sikkerhed, hvormed traditionen har fastholdt mindet om den gamle kultplads. Narnet Gammel kirke er i Kastrup blevet knyttet til stedet, og

๑) Inger M. Boberg i Danske Studier 1931, s. 29. 
generation efter generation er traditionen blevet fortalt, efterhånden $\mathrm{i}$ afbleget form.

Vi kan nu i lyset af denne tradition give en skildring af, hvad der er sket, dengang man ca. 100 år efter Ǩr. f. anlagde og indviede denne plads som en offerplads. Vi vil i denne skildring bevæge os på absolut sikker grund, idet vi nøjes med at fortælle, hvad udgravningen direkte har fortalt os.

Efter at et ældre anlæg var fjernet, begyndte man med at pløje hele pladsen; muligvis benyttede man 2 forskellige redskaber, i hvert fald pløjede man i 3 retninger hen over stedet. Derved fik det grå sandlag sin tykkelse og sin farve. Derefter rev man pladsen, så det фverste af sandet blev ganske fri for sten.

Inde midt på pladsen gravede man et lille hul, og deri nedsatte man et større lerkar. Forinden havde man deri nedlagt en hel del sager; et jernsværd blev bøjet sammen og lagt $i$ bunden, en broncekedel blev slået i sø̆nder og lagt ovenpå, spyd, kniv, skjoldbule, drikkehorn og adskilligt andet fulgte med. Et stykke fårek $\varnothing d$ fik også plads, og en person måtte for sin part give afkald på sin lillefinger og medgive guden. Således nedsatte man lerkarret, men det stod ikke dybere, end at halvdelen nåede op over randen. Den jord, som man havde taget op af hullet, brugte man til at lægge på lerkarrets overdel for at beskytte det mod varmen fra det bål, som man derefter tændte over det.

Også til bålet har man of ret forskelligt, deriblandt et drikkehorn, og det har sikkert været et højdepunkt $\mathbf{i}$ denne indvielsesceremoni, at offerpræsten har hældt den hellige drik ud $i$ bålet og derefter også overgav drikkehornet til flammerne. Bålet har man slukket og dækket med fint, hvidt sand, som man stakkede op i en kegle.

Når vi siger, at dette er sket i umiddelbar følge, så er vi på sikker grund. Det skal jo ikke forstås således, at dermed er indvielsesceremonien udt $\varnothing$ mmende skildret, der kan være foregået meget, som ikke har efterladt sig spor, men fundet fortæller umiddelbart, at således er det foregået. Og sikkert har heller ikke sandbunken fået lov til at ligge ret længe - - det kunne den ikke - den er straks blevet dækket af den store stendynge på 
$3 \times 4 \mathrm{~m}$. Det er så meget naturligere, som vi vil se, at stendyngen var det egentlige. Alt det foregående ville være genstandsløst uden den, for det var en stendynge, man ville rejse. En stendynge var nemlig dengang en helligdom, et alter, et kultisk instrument.

I den islandske litteratur forekommer om helligdomme foruden ordet hov også ordet hørg. Dette ords grundbetydning er en stendynge, som er et alter for en bestemt gud. I et eddadigt siger guden Frøja om en af sine trofaste dyrkere, Ottar Insteinss $\phi$ n fra Hordaland: »Han lavede mig en hørg af opdyngede sten, han overg $\varnothing d$ stenen med friskt okseblod, Ottar troede altid på asynjer. ${ }^{10}$ ) Omvendt fortælles det om Olav Trygres $\phi n$, at alle de steder, hvor han blev konge, og hvor almuen tog den rette tro, lod han brænde hovene, men bryde hørgene og rejse kirker i stedet, som han forsynede med præster. Af disse og andre udtryk fremgår det klart, at h $\phi$ rg betyder stendyngehelligdommen i fri luft og hov det tømrede gudehus. Dog er i Danmark h $\phi$ rge ikke knyttet til gudenavne.

Det er altså en sådan hørg, en stendyngehelligdom, vi har for os i Kastrup. Det er denne stendynge, som har veret genstand for eller i hvert fald midtpunkt for de religiøse ceremonier, som er foregået om den. Offerdyngen med de mange potteskår og̣ nogle få mere betydelige of re er så resultatet af disse of ringer. Vi har ingen mulighed for at få at vide, hvori disse offerhandlinger bestod. Et fingerpeg indeholdes måske i fortællinger on stendynger, som langt op i kristen tid har varet genstand for dyrkelse.

I 1624 fandtes i en dal på Bornholm »en stenhob opkastet af menneskehånd, bred ovenpå og kaldet et alter «. Heri fandtes mangfoldige kors nedsatte med hår af mennesker og dyr og med klude af forskellig farve. $\mathrm{Og}$ i Lumbsås i Odsherred blev der i 1857 ryddet 3 stendynger, hvori der blev fundet urner med benstumper i de to dynger. Folk, der gik forbi, kastede stadig sten til dyngerne, børn små sten og voksne store sten, eftersom børn begik små synder, men voksne store synder. I alle tre dynger har

10) Hans Ellekilde i Nordens Gudeverden I, s. 178. 
der fra gammel tid stået et kors, hvoraf mindst to var bevaret i 1756. Bø̆nderne i Lumbsås holdt dem dengang vedlige, de troede, at de ingen lykke og held skulle have $i$ deres gårde, hvis. disse kors forgik. ${ }^{11}$ )

Det er tidligere anf $\varnothing \mathrm{rt}$, at of ringerne ved Kastrup sandsynligvis omfattede een ejendommelig skik, at man ofte nøjedes med at ofre et skår $\mathbf{i}$ stedet for et helt lerkar (med indhold), altså of rede en lille del af noget. Selv om dette næppe kan bevises, kan Kastrup i hvert fald opvise eet sikkert eksempel på denne praksis: lillefingerleddet $i$ det centrale lerkar. Så lille denne knogle er, kræver den en forklaring, for den kommer der jo ikke af vanvare. Fåret, hvis knogler også fandtes i lerkarret, er dog uden tvivl blevet ofret ved indvielsen, men mennesket slap med at afgive sin lillefinger. Når man nu ved, at menneskeof ringer fandt udstrakt anvendelse $i$ oldtiden, kan der vist ikkevere tvivl om, at denne lillefingerofring skal vare en erstatning for et menneskeoffer, som man denne gang ikke fandt det n $\phi d-$ vendigt at gå til.

Og så voksede offerdyngen da i ca. 100 år, og det er tidligere fremhævet, at den bredte sig så ligeligt til alle sider, at man lettest forklarer det ved, at der har varet et midtpunkt på stendyngen. Og der er et fund fra Broddenbjerg mose ved Viborg, som st $\varnothing$ tter denne tanke. Her fandtes en stendynge og midt $i$ den stod et primitivt træbillede af en mandlig frugtbarhedsgud. Midtpunktet behøver ikke at have varet et gudebillede. For cksempel fandtes på Øland endnu 1634 en stendynge med en større kuglerund sten midt på. I den var indhugget to fordybninger, så det lignede øjne. Også andre tilfælde kendes, hvor det. bare var en stor, bred sten, der var helligdommens sæde.

At dømme efter skårene er ofringerne fortsat således i ca. 100 âr. I begyndelsen af yngre romertid, omkring $200 \mathrm{e}$. Kr. f. eller lidt senere har ceremonierne ændret sig og offerdyngen voksede ikke mere. Vi kender ikke grunden til disse forhold, men måske har der ligefrem været en tid, hvor anlæget var ude af brug.

11) Hans Ellekilde i Nordens Gudeverden I, s. 497. 
Jord blev lagt omkring det yderste af offerdyngen, hvorved hele pladsen blev st $\varnothing$ rre og senere blev hele forh $\varnothing j n i n g e n$ brolagt.

Men hvad denne brolagte forhøjning har tjent til, derom tier historien, for det har ploven taget. Kun så meget kan siges, at når sagnene forbinder stedet med Gram kirkes opf $\varnothing$ relse, så må det betyde, at kultpladsen $i$ Kastrup har været $i$ brug helt op til kristendommens indf $\emptyset$ relse.

Sandsynligvis vil denne unders $\varnothing$ gelse i Kastrup længe være den eneste $i$ sin art, der giver os et indblik i den tids gudsdyrkelse, og mange enkeltheder er endnu vanskeligt forståelige, men den er samtidigt et smukt eksempel på, at folkemindeforskning og arkæologi rækker hinanden hånden $i$ bestræbelsen for at forstå den åndelige side af de håndgribelige ting, som selve udgravningen alene kan beskæftige sig med. 